\title{
4 The BRI in Latin America
}

\author{
New Wine in Old Bottle?
}

Matt Ferchen ${ }^{\prime}$

\begin{abstract}
Chapter 4 examines the role of the BRI in relations with Latin America and the Caribbean. Prior to 2017, Chinese officials rejected the idea that these regions were part of the BRI. While the BRI was geographically expansive, the Western Hemisphere appeared beyond its scope. However, in 2017, China started to sign BRI memoranda of understanding (MoUs) and BRI-related deals with governments in Central America, the Caribbean, and South America. This expansion of the BRI to the region occurred as the US began a concerted pushback against Chinese dealmaking and influence. This chapter offers an overview of the BRI's still-short history in Latin America and the Caribbean. It analyses what the BRI means in the context of China's developing country diplomacy in the region, and how it is playing out against widening US-China strategic rivalry.
\end{abstract}

Keywords: Belt and Road Initiative, China, South America, Caribbean, Central America, agency

Latin America has been, and continues to be, an outlier in terms of its relationship to China's Belt and Road Initiative (BRI). Geographically, Latin America has rarely appeared on the wide array of BRI maps produced inside

1 Unlike some of the other chapters in this study, the author did not conduct field work for this chapter. He has, however, worked extensively on the Latin America-China relationship since 2008. In addition to publishing academic and policy research on a range of China-Latin America issues, he also taught courses on China-Latin America relations and Latin American political economy in the Department of International Relations at Tsinghua University from 2008 to 2017. The author wishes to thank Lily Sprangers and Florian Schneider for their thoughtful feedback on earlier drafts of this chapter and chapter 10 and for support throughout the project.

Schneider, Florian (ed.), Global Perspectives on China's Belt and Road Initiative: Asserting Agency through Regional Connectivity. Amsterdam, Amsterdam University Press 2021 DOI: 10.5117/9789463727853_CHO4 
or outside of China. Latin America also did not feature in the original rollout of the New Silk Road concept or subsequent formulations explaining the combination of maritime and land-based corridors. The BRI has become known for its geographic expansiveness and overall programmatic ambiguity, inclusive not just of wide swaths of Asia but also Africa and Europe and even the Arctic (see the Polar Silk Road). However, the exclusion of the entire Western Hemisphere, including Latin America and the Caribbean, had long been a clear exception. Since around 2017, however, this has all changed. Almost 20 countries in Latin America and the Caribbean (LAC) are now at least signatories to BRI memoranda of understanding (MoUs) and/or are actively exploring BRI-branded projects. ${ }^{2}$

Yet to understand where the Latin America and the Caribbean region fits in the context of the BRI requires taking a step back to the decade prior to the introduction of the BRI itself. The diplomatic and commercial relationship between China and Latin America and the Caribbean really took off in the period around 2003-2004, based in no small part on a China-led commodity boom that saw the rapid expansion of Chinese demand for South American raw materials (Ferchen 2011). The contours of the relationship between China and Latin America and the Caribbean that were established during that time - the potential, the challenges, the disappointments - all set the tone for discussions today of the BRI in the region. In particular, concerns about commodity dependence and the unsustainable environmental and social impacts of ties between China and Latin America and the Caribbean, all of which were already clear well before the rollout of the BRI, have only been accentuated by the extension of the BRI to the region. At the same time, hopes that China would become a stable, long-term development partner for the region have also received a boost from the BRI's arrival.

Therefore, familiarity with the history of Latin America and the Caribbean's relations with China is key to any understanding of how the BRI is being rolled out and responded to inside and outside the region. In addition, because this history is so foundational to any understanding of where the BRI fits into the broader relationship between China and Latin America and the Caribbean, it is also important to ask how the extension of the BRI to Latin

2 As will become apparent in the body of this chapter, the LAC region's diversity has important implications for trade and investment relations with China. While South America was the focal point for most commodity-based trade and investment relations in the period before the extension of the BRI to the region, it is largely the Caribbean and Central America where most BRI-related activity has been focused in the years since 2017 . 
America and the Caribbean does or does not change the broader economic and political patterns that had already come to define the relationship.

Against this backdrop a key question is: What, if anything, is significant and new in the relationship between China and Latin America and the Caribbean as a result of the introduction of the BRI? The answer is that in many ways the introduction of the BRI to Latin America and the Caribbean has not fundamentally altered structural patterns already at play since the early 1990s. However, the BRI's introduction to the region has accentuated some of these patterns, including a growing wariness of China's presence in the region by the United States.

In a way significant to the broader comparative study of the BRI, the combination of hope and disappointment about the potential of China's developmental role in Latin America and the Caribbean is mirrored in other BRI regions like Africa and South and Southeast Asia. This is no coincidence. Prior to the introduction of the BRI, Latin America and the Caribbean had already become an important part of China's broader developing-country diplomacy and commercial outreach (Eisenman \& Heginbotham 2018). Africa, in particular, has been the other core element of China's twenty-first-century developing country diplomacy, a region that has long been at the heart of China's longer standing efforts to be seen as a leader and representative of the 'Third World' (Strauss 2009). ${ }^{3}$ In this regard, key features and challenges of the developmental relationship between China and Latin America and the Caribbean, including trade dependency, debt sustainability, and environmental and social impact issues, have also appeared prominently in the analytical and policy debates surrounding the impact of the BRI in regions covered in other chapters of this study. One question that emerges from this chapter, then, is: What lessons are or are not being learned in a comparative context across BRI countries and regions that share similar developmental challenges and aspirations in their ties to China?

\section{Relations between China and Latin America and the Caribbean: The BRI's Pre-history}

At least a decade before the BRI was introduced by Xi Jinping in 2013, resource-rich countries in South America had already begun to experience

3 For an excellent overview of the Mao-era roots of China's efforts to vie for symbolic and revolutionary leadership of the 'Third World', see Friedman (2015). 
a boom in exports to China. Even within South America, this trade-based take-off in relations with China was concentrated in a relatively small number of countries and commodity types. Countries rich in minerals such as copper (Chile) and iron ore (Brazil), agricultural resources such as soy (Argentina, Brazil and Uruguay), and fossil fuels such as oil and gas (Argentina, Brazil and Venezuela) all quickly saw China become a number one or number two export partner in the years after 2003 (Gallagher 2016). Booming, commodity-based trade relations were also accompanied by a flurry of high-level diplomatic exchanges, highlighted by then-President of China Hu Jintao's signature visit to Brazil in 2004. These diplomatic exchanges were part of a renewed Chinese effort to reinvigorate ties to developing countries, including those in Africa and Asia (Eisenman \& Heginbotham 2018).

Geopolitically, the take-off in China's commodity-based trade relations with South America also coincided with the rise of the 'New Left' in some of China's newly rediscovered trade partners. This included, most notably, the coming to power of Luiz Inácio Lula da Silva in Brazil and of Hugo Chavez in Venezuela (Schamis 2006). In the decade after 2003, China's rapidly expanding trade and investment ties throughout South America were not primarily determined by political considerations. However, China did establish especially close bilateral political ties with some New Left leaders in the region (for example, Chavez in Venezuela and Rafael Correa in Ecuador) and also played up a kind of emerging market solidarity with others (for example, with Brazil and the other countries of the BRICS grouping, Russia, India, and South Africa).

Yet this boom in China-South America trade and diplomatic relations did not play out in the same way in other parts of Latin America and the Caribbean. Notably, Mexico and countries in Central America and the Caribbean, which did not possess the same kinds of commodity endowments as their South America neighbours, did not experience the same kind of export-driven trade boom with China. Mexico, the second-largest economy in Latin America and the Caribbean, has experienced relations with China that have been distinctly more competitive, and less 'complementary', than those of most of its South American counterparts (Dussel Peters 2015). Even though Mexico has significant oil resources, its trade relationship with China has not been characterized by buoyant commodity exports to China, but instead by competition with China for assembly and export to third markets, including the United States. Moreover, Mexico's competitive trade relationship with China, including Mexican concerns about a large and sustained trade deficit with China, has also limited the kind of diplomatic 
amity that accompanied the trade-based boom in China-South America relations.

Although not as competitive as the Mexico-China relationship, the Spanish-speaking countries of Central America, as well as the relatively small, diverse countries of the Caribbean, also generally found themselves searching for viable sources of goods or services exports to China. This was even as they saw both the commercial and diplomatic potential of the expanded ties between their South American neighbours and China. In part because of the smaller size and relatively lower levels of economic development in Central America and the Caribbean, as well as the fact that many countries in the region recognized Taiwan rather than the People's Republic of China (PRC), China's stadium and road building, as well as generally more 'aid'-based activities, were a distinctive and prominent feature of its approach to the region prior to the introduction of the BRI (DeHart 2018). Overall, then, it is clear that in the years prior to the introduction of the BRI, South America was the region of Latin America and the Caribbean with the most dynamic economic and diplomatic relations with China.

If much of the dynamism and optimism of the boom years in relations between China and Latin America and the Caribbean was based in commodity-exporting South America, then many of the challenges and concerns were also concentrated there. China insisted on the 'win-win' benefits of commercial 'complementarity' (i.e. South America had the natural resources China needed). However, at least some South American governments and multilateral institutions worried, even during the height of the commodity boom, that the trade relationship with China looked uncomfortably similar to 'dependent' trade relations between Latin America and the Caribbean and North America or Europe in the nineteenth and twentieth centuries (Ferchen 2011; Stallings 2020). Dilma Rousseff, newly inaugurated as Brazil's president in 2011, thus felt compelled to insist that Brazil-China relations move 'beyond complementarity' (Ministry of Foreign Affairs 2011).

Whereas China's ability to maintain strong demand for South American commodities in the wake of the 2008/2009 financial crisis helped the region weather the crisis relatively well, the subsequent end of the China-led 'commodity super cycle', beginning around 2013, has meant that at least some fears of a boom-bust trade cycle have been borne out (Ferchen 2015). Countries such as Venezuela demonstrate this dynamic most clearly: ChinaVenezuela trade and diplomatic relations blossomed at the height of the commodity boom, but have run into extreme difficulties in the wake of Venezuela's ongoing post-commodity boom economic and political crisis. 
Venezuela also highlights how patterns of official Chinese state lending to some resource-rich Latin American countries at the height of the boom presaged some of the broader BRI-related concerns about the sustainability of Chinese 'development' lending in other regions as well (Ferchen 2018).

Thus, even if the boom years in the South America-China relationship were not altogether smooth, then the post-boom period has caused a good deal of reflection about what can and should sustain the economic and political relationship in a more stable and equitable way. Moreover, if there were challenges in the commodity-based, South America-China relationship, the countries of the Caribbean (see Gonzalez-Vicente, Chapter 7 in this volume) and Central America, as well as Mexico, were still left wondering how they could better link their own development and even diplomatic options to China. For some, the BRI has emerged as a symbol of a possible path forward. However, given the slow and tentative pace of China's willingness to extend the BRI to Latin America and the Caribbean, at least initially, and given the already clear and entrenched relationships between China and the region in the years directly before the launch of the BRI, the transformational potential of the BRI has so far remained limited at best. Yet surprisingly, it is in the Caribbean and Central America where the BRI has so far gained momentum.

\section{The BRI Finally Arrives: 2017 and New, Tentative Rollout of the BRI in the Americas}

For more than three years after the BRI was first introduced in 2013, there was much speculation among observers of relations between China and Latin America and the Caribbean about whether, and when, the initiative would be extended to the Americas. ${ }^{4}$ In September 2013, Xi Jinping introduced what would become known as the BRI in Kazakhstan, where it was formulated as the 'Silk Road Economic Belt'. Shortly afterward, in Indonesia, Xi announced plans for the '21st-Century Maritime Silk Road'. These introductions of the BRI highlighted that both the maritime and continental components of the BRI would be, at least initially, focused on China's Southeast and Central Asian neighbourhoods. Subsequent formulations of the BRI extended its

4 Based in Beijing from 2004 to 2017, the author participated in scores of academic, think tank, government and business community discussions among Chinese and LAC region participants about the China-Latin America relationship. Beginning around 2014, as the BRI concept picked up momentum, a common theme at such discussions was whether and when the BRI would be extended to Latin America and the Caribbean. 
geographic scope to Africa and then on to Europe, as a final destination for the convergence of both maritime and continental components. A muchcited official statement, published in 2015 by the National Development and Reform Commission and describing the aims of the BRI, stated: 'The Belt and Road Initiative aims to promote the connectivity of Asian, European and African continents and their adjacent seas' (NDRC 2015). The document therefore clearly omits the entire Western Hemisphere. Furthermore, the most recent 2016 official Chinese foreign policy document, or 'white paper', on relations between China and Latin America and the Caribbean, makes no mention of the BRI (State Council 2016). Clearly, as expansive, ambiguous, and often open-ended as the BRI has been, the Latin American and Caribbean region appears to at least initially have been seen by Chinese officials as simply beyond the project's core scope.

Yet in 2017 this all began to change. One important symbolic precursor to the rollout of the BRI in the region took place at the inaugural BRI forum in Beijing. There, Xi Jinping, speaking with then Argentine President Mauricio Macri, noted that the Latin America and Caribbean region was a 'natural extension' of the Maritime Silk Road (Barrios 2017). Similar official Chinese statements began to note that some countries in Latin America and the Caribbean could be important 'nodes' in the BRI network. Such comments were further bolstered by a 'Special Declaration on the Belt and Road', which was signed by officials from China and Latin America and the Caribbean at the first China-Community of Latin American and Caribbean States (CELAC) Ministerial Summit in January 2018.5

These symbolic, yet often still vague, statements indicated that both China and some countries in Latin America and the Caribbean were beginning to consider forms of participation under the rubric of the BRI. However, the truly catalytic BRI activities in the region began with a series of BRIthemed diplomatic and commercial agreements in Central America and the Caribbean. What is taken as inclusion in the BRI, or whether a country is considered as being 'in' or not, is still a largely nebulous and disputed category. However, one measure that has come to serve as a proxy is the signing of MoUs or other forms of BRI-themed 'cooperation agreements'. 6

5 The China-CELAC forum is similar in conception to the Forum on China-Africa Cooperation (FOCAC) but is newer and less institutionalized.

6 For instance, the Chinese government's official English language 'Belt and Road Portal' (https://eng.yidaiyilu.gov.cn/index.htm) lists 'partnership' countries defined as 'countries along the Belt and Road and countries that have signed cooperation agreements with China on Belt and Road Initiative'. This categorization is so expansive, though, that over 140 countries appear on the list. 
Panama was a bellwether: in June 2017, it switched its diplomatic recognition from Taiwan to the People's Republic of China and in November of the same year it also signed the first Latin American and Caribbean BRI MoU with China (Zhang 2018). In 2018, the Dominican Republic and El Salvador both followed suit by changing their diplomatic recognition and the Dominican Republic also signed a BRI MoU (Ellis 2018). Altogether, between 2017 and 2019, at least nineteen countries, the majority in Central America and the Caribbean, signed BRI MoUs or joint statements promoting BRI cooperation. ${ }^{7}$ In many of these cases, not only did Latin American and Caribbean countries make generally supportive statements about the BRI, but they also announced new infrastructure and commercial cooperation deals. Regardless of whether any of these deals are 'officially' designated as BRI projects by either the host government or by China (many of them are still on the drawing board or only partially completed), the symbolic connection between the MoUs and the announcement of projects such as ports, highways, and industrial parks is clear.

As such, 2017 was a turning point at least in terms of a series of BRI-themed MoU signings and associated infrastructure deals between China and Latin America and the Caribbean. But what are we to make of the relevance of this trend, especially in light of the history of relations between China and Latin America and the Caribbean that has been outlined above? One element that stands out is the concentration of Caribbean and Central American countries in the BRI-themed MoUs and related commercial deal announcements. As noted above, the real weight and momentum of the relationship between China and Latin America and the Caribbean has largely been with the commodity-rich countries of South America. One explanation for the relative concentration of BRI-themed announcements and dealmaking in Central America and the Caribbean is simply that those regions had untapped potential, especially in the area of highway and port infrastructure (see Gonzalez-Vicente, Chapter 7 in this volume). At the same time, because the BRI has a firmly established reputation as Xi Jinping's signature foreign policy project, governments in Latin America and the Caribbean have likely been willing to sign MoUs and brand certain projects as part of the BRI out of political as much as economic calculation. For the countries of Central America and the Caribbean that had long sought more commercial opportunities with China, signing on to the BRI may appear a low-cost gesture to facilitate Chinese lending and investment that had hitherto been in short supply.

7 See the following website for an unofficial listing of BRI MoUs to date: https://www.beltroadinitiative.com/memorundum-of-understanding-belt-and-road-initiative/. 
Regarding those countries in South America such as Venezuela, Ecuador, and Bolivia that have also signed BRI MoUs, such signings fit with these countries' close, and often politicized, diplomatic ties to China (Liévano 2019). ${ }^{8}$ They too are likely to have calculated that the signing of BRI agreements would, on balance, offer more dealmaking opportunities. Venezuela President Nicolas Maduro may also have hoped that signing BRI agreements would be of help in his efforts to retain China's diplomatic recognition and forbearance given Venezuela's limited ability to meet its debt and oil-export obligations to China. Of course, as notable as which countries have chosen to sign BRI-themed MoUs or deals is which ones have not. Neither Brazil nor Mexico, the two biggest countries in Latin America and the Caribbean, nor many of the South American countries at the core of commodity-based ties to China (with the exceptions of Chile and Peru), have signed such statements. For such countries, it may not be obvious what the benefits of signing BRI MoUs or BRI-themed infrastructure deals are, especially compared to similar previous efforts. In fact, doing more infrastructure deals has long been on the table in relations between China and Latin America and the Caribbean. While some of that cooperation has indeed come to fruition (even if attended by controversy), many other deals have been left on the table or scuttled altogether (Myers 2018).

Whatever the motives that lead Latin American and Caribbean countries to engage in, or refrain from, BRI-themed dealmaking with China, one clear element of what is new about the relationship between China and the region since 2017 is the attitude taken by the United States towards dealmaking between China and Latin American and Caribbean countries. The entrance, or extension, of the BRI into Latin America and the Caribbean since 2017 has coincided with a much more critical US government attitude towards China's role and influence in the Americas. It may be pure coincidence that the Trump administration came into office in 2017 at the same time as the Latin American and Caribbean BRI-themed MoUs and deals in that year were announced. However, what is clear is that the United States has taken a dim view of at least some of this BRI-themed dealmaking, especially in places like Panama. In Panama, the BRI MoU and related Panama Canal upgrade deals with China were also accompanied by Panama's change from diplomatic recognition of Taiwan to recognition of the PRC. US Secretary of State Mike Pompeo, in a visit to Panama in October 2018, made clear US concerns about China's role in the country (Wong 2018). Just a month

8 Peru also signed a MoU in 2019, although its ties to China have not been part of the 'New Left' foreign policy that has characterized some of its Andean neighbours. 
before that visit, the US temporarily recalled its top diplomats from Panama, as well as the Dominican Republic and El Salvador, over their decisions to withdraw diplomatic recognition from Taiwan (Webber 2018). While Venezuela's troubled ties to China were in place well before the BRI was born or Venezuela signed any BRI MoUs, the United States has in recent years highlighted Venezuela as one of the Latin American countries where Chinese financial deals have led to insalubrious results (Gunia 2019). While the BRI per se is not the reason for, or primary focus of, heightened US-China strategic competition in Latin America and the Caribbean, it is a potent symbol of China's presence and a lightning rod in the increasingly heated US-China great power competition.

Beyond the renewed diplomatic and dealmaking activity with China in Central America and the Caribbean, and a growing US pushback against China's presence in the region, there are a few other answers to what is 'new' in the relationship since the BRI's at least partial expansion to the region. Chinese-backed infrastructure development, while on the table for many years, has seen an uptick in recent years. Port developments in the Caribbean are one example, while electricity infrastructure deals, including in Brazil's electricity grid, are another (Myers 2018). Again, some of those transport infrastructure deals in the Caribbean and Central America are tied to BRI MoUs or otherwise branded as BRI projects by host governments and China, while energy grid deals in Brazil do not bear any obvious BRI stamp (Andreoni 2019).

In addition to transport and energy infrastructure deals, two additional elements of BRI 'connectivity'-themed developments merit mention in any assessment of what is 'new' in relations between China and Latin America and the Caribbean in recent years. The first component is activities branded as part of China's 'Digital Silk Road'. In addition to transport infrastructure like roads, railways, and ports, as well as energy infrastructure like dams, coal-fired power plants, and energy grids, Chinese officials have been keen to include digital infrastructure and digital connectivity as part of the BRI (Eder et al. 2019). In the case of South America, a fibre-optic cable across the Atlantic from Africa to Brazil has been at least partially financed, built, and operated by Chinese firms. A similar cable across the Pacific from China to Chile was under discussion until the contract was given to a Japanese firm (Huawei Marine 2018; Hirose \& Toyama 2020).

A second and more recent development is renewed discussion about the role of a 'Health Silk Road'. First proposed in 2015, China's National Health and Family Planning Commission formulated a plan to build health cooperation (Bing 2020), including 'infectious disease prevention and control', into 
the overall BRI framework. While largely focused on neighbouring countries in Southeast Asia, the Health Silk Road concept has gained new life, and attracted new controversy in light of the 2020 COVID-19 pandemic. The relevance for relations between China and Latin America and the Caribbean of cooperation under the rubric of the New Health Silk Road, as a kind of supplement to the BRI, has yet to be seen beyond an initial public diplomacy push and potential donations or sales of personal protective equipment, testing kits, and medical machines (Escobar 2020).

\section{Conclusion}

This overview of the BRI in Latin America and the Caribbean underscores how relatively new and partial the extension of the BRI, per se, is in the region. It also underscores how, even with the arrival of the BRI, much remains unchanged about the nature and dynamics of relations between China and Latin America and the Caribbean. Questions remain about the sustainability and equality of trade relations, especially commoditydependent exports from South America and concerns about trade deficits in Mexico. In other words, structurally, the relationship contains many elements of Latin American commodity dependency on Chinese demand (Stallings 2020). This is especially a concern in the wake of the COVID-19 crisis given that it is unlikely that China will be able to play the role of demand-side saviour for South American commodity exports during the global economic downturn that has already begun. ${ }^{9}$ As the chapter on the China-Caribbean relationship by Gonzalez-Vicente (Chapter 7 in this volume) highlights, China's role in the region has complicated many of the longstanding and unresolved questions about sustainable foreign investment and financial relations. Overall, China's role in Latin America and the Caribbean, including through the recent introduction of the BRI, has had contradictory impacts on the region's development prospects.

How the BRI underscores such longstanding contradictions is also borne out in other aspects of the relationship between China and Latin America and the Caribbean. For instance, academic and civil society discussions about whether the BRI will or will not change corporate social responsibilitytype (CSR) concerns about environmental and local community impacts

9 Media commentary that China is gaining geopolitical ground in Latin America and the Caribbean through its 'mask diplomacy' in the wake of the Corona crisis miss these bigger structural challenges. For example, see Stott (2020). 
of Chinese investments in the Amazon or the Andes are little different today from the era when the BRI had not yet reached the Americas (Ray et al. 2017). Even the US pushback against China's role in Latin America and the Caribbean seems less about the BRI per se and more about longer-term structural shifts in US-China relations.

Yet pondering the role and relevance of the BRI in Latin America and the Caribbean does offer an opportunity to place questions of learning and lesson-sharing in a comparative regional and historical perspective. In many ways, discussions about the role of the BRI in Latin America and the Caribbean demonstrate the combination of enthusiasm and anxiety that has characterized views from countries across the region since the early 2000s. In the early days of the relationship, there was both Chinese and Latin American and Caribbean regional enthusiasm (not to mention politicized boosterism) about the arrival of China in the region as a new commercial and diplomatic partner. As noted above, though, questions soon emerged about the quality and sustainability of those partnerships, questions that were tested and answered in different and sometimes contradictory ways after the 2008/2009 financial crisis and in the wake of the end of the commodity boom after 2013. In some ways, the entry of the BRI into the region has stoked similar questions about what new dimensions the BRI could bring to a relationship with well-entrenched patterns, challenges, and problems.

One theme that was always present throughout these pre-BRI years was the extent to which Latin American and Caribbean countries were passive or active players in relationships in which it almost always seemed to be the Chinese side that had proactive commercial or diplomatic strategies for regional or bilateral ties. As a Chinese initiative, the BRI has prompted similar questions with similar answers; as a region, Latin America and the Caribbean has not presented itself as a coherent actor. The consequence has been that the region is almost always a passive or divided player compared to China. Yet the reality has almost always been more complex. On the Chinese side, different Chinese government banks or firms, not to mention private firms, have adopted tailored approaches depending on the country or economic sector in which they are lending or investing. On the Latin American and Caribbean side, different countries have long adopted different approaches to diplomatic and commercial ties to China. On the ground, Latin American and Caribbean businesses, civil society actors, and researchers have been keen to learn and adapt to the opportunities or challenges they have seen with China's rising presence in the region. The BRI offers a new framework in which these long-established patterns will continue to play out. 
One last note on the linkage between agency and learning regards the question of whether or not, and how, different Latin American and Caribbean actors have learned from one another or from counterparts in other regions about China-specific challenges and opportunities. It is often striking how many government, business, civil society, or researcher discussions about relations between China and Latin America and the Caribbean countries sound like echoes of similar conversations, either in neighbouring countries or in other regions, such as Africa or Southeast Asia (Ferchen 2020). Who are the Chinese banks or companies involved in a package loan-for-infrastructure deal? Are Chinese businesses and government bureaus learning from past experience on CSR environmental or local community impact issues? Do the experiences gained from regional groupings such as ASEAN, 17+1, and FOCAC offer lessons for the relatively new China-CELAC regional forum (see Jakóbowski 2018)? The potential for academic and policy 'learning' would be greatly enhanced through ever more comparative research addressing these and similar questions.

\section{References}

Andreoni, Manuela (2019, August 9). 'China Bets on Wind and Solar Power in Brazil'. Diálogo Chino. Retrieved 19 November 2019 from https://dialogochino. net/en/climate-energy/29559-china-bets-on-wind-and-solar-power-in-brazil/.

Barrios, Ricardo (2017, July 18). 'China's Belt and Road Lands in Latin America'. InterAmerican Dialogue. Retrieved 17 September 2017 from https://www.thedialogue. org/analysis/chinas-belt-and-road-lands-in-latin-america/.

Bing, Ngeow Chow (2020, May 26). 'COVID-19 Speeds up China's "Health Silk Road”. East Asia Forum. Retrieved 29 May 2020 from https://www.eastasiaforum. org/2020/05/26/covid-19-speeds-up-chinas-health-silk-road/.

DeHart, Monica (2018). 'China-Costa Rica Infrastructure Projects: Laying the Groundwork for Development?' In Enrique Dussel Peters, Ariel Armony \& Cui Shoujun (eds.), Building Development for a New Era: China's Infrastructure Projects in Latin America and the Caribbean (pp.3-23). Mexico City: Asian Studies Center, Center for International Studies, University of Pittsburgh, and Red Académica de América Latina y el Caribe sobre China.

Dussel Peters, Enrique (2015, September 16). China's Evolving Role in Latin America: Can It Be a Win-Win? Atlantic Council. Retrieved 14 November 2015 from https:// www.atlanticcouncil.org/in-depth-research-reports/report/china-s-evolvingrole-in-latin-america-can-it-be-a-win-win/. 
Eder, Thomas; Arcesati, Rebecca \& Jacob Mardell (2019, August 28). 'Networking the "Belt and Road" - The Future is Digital'. Mercator Institute for China Studies. Retrieved 3 December 2019 from https://merics.org/en/analysis/networkingbelt-and-road-future-digital.

Eisenman, Joshua \& Heginbotham, Eric (eds.) (2018). China Steps Out: Beijing's Major Power Engagement with the Developing World. New York: Routledge.

Ellis, Evan (2018, August 21). 'El Salvador Recognizes the PRC: Confrontation on the FMLN's Way out the Door'. Global Americans. Retrieved 27 August 2018 from https://theglobalamericans.org/2018/o8/el-salvador-recognizes-the-prcconfrontation-on-the-fmlns-way-out-the-door/.

Escobar, Pepe (2020, April 2). 'China Rolls out the Health Silk Road'. Asia Times. Retrieved 8 April 2020 from https://asiatimes.com/2020/04/china-rolls-outthe-health-silk-road/.

Ferchen, Matt (2011). 'China-Latin America Relations: Long-term Boon or Short-term Boom?' Chinese Journal of International Politics, 4(1), 55-86.

Ferchen, Matt (2015, January 9). 'China, Latinoamérica y el fin del auge de las materias primas' [China, Latin America, and the end of the commodity boom]. El País. Retrieved 9January 2015 from https:/elpais.com/internacional/2015/01/07/ actualidad/1420651906_278565.html.

Ferchen, Matt (2018, August 16). 'China, Venezuela, and the Illusion of Debt-Trap Diplomacy’. AsiaGlobal Online. Retrieved 16 August 2018 from https://www. asiaglobalonline.hku.hk/china-venezuela-debt-trap-diplomacy.

Ferchen, Matt (2020, January 8). 'How China Is Reshaping International Development'. Carnegie Endowment for International Peace. Retrieved 8 January 2020 from https://carnegieendowment.org/2020/01/08/how-china-isreshaping-international-development-pub-80703.

Friedman, Jeremy (2015). Shadow Cold War: The Sino-Soviet Competition for the Third World. Chapel Hill: University of North Carolina Press.

Gallagher, Kevin (2016). The China Triangle: Latin America's China Boom and the Fate of the Washington Consensus. Oxford: Oxford University Press.

Gunia, Amy (2019, April 16). “Mr. Pompeo, You Can Stop”: China Refutes “Despicable” US Criticism of Its Involvement in Venezuela'. Time. Retrieved 28 September 2019 from https://time.com/5571403/china-us-latin-america-venezuela/.

Hirose, Yohei \& Toyama, Naoyuki (2020, July 29). 'Chile Picks Japan’s TransPacifıc Cable Route in Snub to China'. Nikkei Asian Review. Retrieved 30 July 2020 from https://asia.nikkei.com/Business/Telecommunication/ Chile-picks-Japan-s-trans-Pacific-cable-route-in-snub-to-China.

Huawei Marine (2018, September 5). 'South Atlantic Inter Link Connecting Cameroon to Brazil Fully Connected'. Press release. Retrieved 23 January 2020 from http://www.huaweimarine.com/en/News/2018/press-releases/pr20180905. 
Jakóbowski, Jakub (2018). 'Chinese-Led Regional Multilateralism in Central and Eastern Europe, Africa and Latin America: $16+1$, FOCAC, and CCF'.Journal of Contemporary China, 27(113), 659-673.

Liévano, Andrés Bermúdez (2019, June 18). 'China's Belt and Road Advances in Latin America's Andean Region'. Diálogo Chino. Retrieved 22 June 2019 from https:// dialogochino.net/en/infrastructure/27815-chinas-belt-and-road-advances-inlatin-americas-andean-region/.

Ministry of Foreign Affairs (2011, April 8). 'President Dilma Rousseff to Visit the People's Republic of China - Beijing, April 12-13, 2011'. Government of Brazil. Retrieved 9 June 2011 from http://www.itamaraty.gov.br/en/press-releases/1656o-presidentdilma-rousseff-to-visit-the-people-s-republic-of-china-beijing-april-12-and-13-2011.

Myers, Margaret (2018, November 13). 'China's Transport Infrastructure Investment in LAC: Five Things to Know'. Inter-American Dialogue. Retrieved 15 November 2018 from https://www.thedialogue.org/blogs/2018/11/ chinas-transport-infrastructure-investment-in-lac-five-things-to-know/.

NDRC (2015, March). 'Vision and Actions on Jointly Building Silk Road Economic Belt and 21st-Century Maritime Silk Road'. National Development and Reform Commission, Ministry of Foreign Affairs and Ministry of Commerce, People's Republic of China. Retrieved 25 October 2020 from https://web.archive.org/web/20181127225143/ http://en.ndrc.gov.cn/newsrelease/201503/t20150330_669367.html.

Ray, Rebecca, Gallagher, Kevin, López, Andres \& Sanborn, Cynthia (eds.) (2017). China and Sustainable Development in Latin America: The Social and Environmental Dimension. London: Anthem Press.

Schamis, Hector E. (2006). 'A "Left Turn" in Latin America? Populism, Socialism, and Democratic Institutions'. Journal of Democracy, 17(4), 20-34.

Stallings, Barbara (2020). Dependency in the Twenty-First Century? The Political Economy of China-Latin America Relations. Cambridge: Cambridge University Press.

State Council (2016, November 24). 'Full Text of China's Policy Paper on Latin America and the Caribbean'. State Council of the People's Republic of China. Retrieved 6 December 2016 from http://english.www.gov.cn/archive/white_paper/2016/11/24/content_281475499069158.htm.

Stott, Michael (2020, August 8). 'China Cleans up in Latin America as US Flounders over Coronavirus'. Financial Times. Retrieved 13 August 2020 from https://www. ft.com/content/741e72ed-e1db-46og-b389-969318f17oe8.

Strauss, Julia (2009). 'The Past in the Present: Historical and Rhetorical Lineages in China's Relations with Africa'. China Quarterly, 199, 777-795.

Webber, Jude (2018, September 8). 'US Recalls Ambassadors over Recognition of China'. Financial Times. Retrieved 9 November 2018 from https://www.ft.com/ content/1bf84e7c-b301-11e8-8d14-6fo49do6439c. 
Wong, Edward (2018, October 19). 'Mike Pompeo Warns Panama against Doing Business with China'. New York Times. Retrieved 25 October 2018 from https://www. nytimes.com/2018/10/19/world/americas/mike-pompeo-panama-china.html.

Zhang, Hui (2018, December 3). 'BRI Projects to Highlight Ties after Xi Visits Panama'. Global Times. Retrieved 5 April 2019 from http://www.globaltimes. cn/content/1130177.shtml.

\section{About the Author}

MATt FERCHEN's research focuses on the connections between China's foreign and domestic political economy. He has written extensively about China's economic statecraft, China's developing country diplomacy, and debates about the 'China model' of development. He is particularly interested in lessons researchers and policymakers can learn from comparisons of China's economic and political relations with different regions, from Southeast Asia to Latin America, Europe, and the United States. From 2008 to 2017 Ferchen was a faculty member in the Department of International Relations at Tsinghua University and from 2011 to 2019 he was a scholar with the Carnegie-Tsinghua Center for Global Policy. In 2020 he was appointed Head of Global China Research with the Mercator Institute for China Studies (MERICS). He has been engaged with LeidenAsiaCentre research since 2017. Ferchen holds an MA from Johns Hopkins School of Advanced International Studies and a PhD from Cornell. 